\title{
The Balance of Contract in Online Insurance Agreements in The Era of Revolution 4.0 (Insurance Products of Several Banks in Indonesia)
}

\author{
Felix Wijaya ${ }^{1}$, Kartina Pakpahan ${ }^{2}$, Velia Toknado ${ }^{3}$ \\ \{xfelixwijaya@gmail.com 1 , kartinapakpahan@unprimdn.ac.id ${ }^{2}$, veliatoknado@gmail.com ${ }^{3}$ \} \\ ${ }^{123}$ Universitas Prima Indonesia
}

\begin{abstract}
Online insurance products are present along with the development of the 4.0 revolution. We as a society or prospective customers must understand the details of online insurance products. The purpose of the study is to determine the balance of contracts, the procedure of agreements, the legal consequences caused by a breach of online insurance agreements. This research uses normative juridical legal research methods. With the development of technology and science, the agreement form has undergone changes and developments. In online insurance agreements, the balance of the contract is regulated in the agreement of the parties stipulated in Civil Code Article 1320. If the online insurance agreement defaults, deliberation and consensus can be done as a solution. However, it fails to be resolved, the settlement can be done through the court or the Indonesian Insurance Mediation and Arbitration Agency or other alternative dispute resolution institutions established by the Financial Services Authority.
\end{abstract}

Keywords: Contract balance, Online Insurance Agreement, Revolution 4.0

\section{Introduction}

The speed of technological development becomes a challenge for its utilization as a tool that can provide fast, precise, and accurate information. To make it happen, it is necessary to support software and human resources that master the use of technology [1]. Industrial Revolution 4.0 gives us a new perspective on social security services. This new trend encourages us to see what the future looks like if we are able to capitalize on this era. The rapid change from the digital revolution to the industrial revolution 4.0 emphasizes the use of computerization, automation, and electronic devices. This era limits the utilization of digital devices with more complexity. Everything uses internet simulations and autonomous robots $[2]$.

In today's technological era, insurance must provide effective and efficient services both to cooperation partners and customers. Business development process must be balanced with optimal services, especially public services through information systems or technology-based applications. The application or incorporation of digital technology has broad benefits such as increased productivity, increased competitiveness, increased flexibility, improved quality, increased innovation, and decreased worker costs [3].

Digital technology offers convenience for the community in carrying out activities in life and also offers great opportunities for businesses for the development section. Insurance companies are one example of businesses taking advantage of opportunities for the 
advancement of digital technology. With the design of online-based applications in the field of insurance and its development, insurance companies in Indonesia can process data both on the submission of death claims and accelerated repayment more easily, thus decrease paper usage to maintain the sustainability of the earth.

Table 1. Comparison of Insurance Assets in Indonesia

\begin{tabular}{|l|l|l|}
\hline Period & 2019 Assets & 2020 Assets \\
\hline January & $1,233,742,761$ & $1,321,668,778$ \\
\hline February & $1,232,859,257$ & $1,303,997,206$ \\
\hline March & $1,249,167,483$ & $1,247,954,704$ \\
\hline April & $1,255,193,574$ & $1,262,755,893$ \\
\hline May & $1,252,203,296$ & $1,271,560,765$ \\
\hline June & $1,282,389,119$ & $1,284,867,077$ \\
\hline July & $1,290,076,426$ & $1,312,705,806$ \\
\hline August & $1,289,872,641$ & $1,331,761,958$ \\
\hline September & $1,289,271,365$ & $1,312,554,207$ \\
\hline October & $733,569,575$ & $1,338,469,126$ \\
\hline November & $1,300,804,980$ & $1,380,981,670$ \\
\hline December & $1,325,746,216$ & $1,409,751,255$ \\
\hline Total & $14,734,896,693$ & $15,779,028,445$ \\
\hline
\end{tabular}

*In units of Millions of Rupiah

The data above was taken from "Insurance Statistics" through the website of the Financial Services Authority [4] and we can conclude that insurance growth in Indonesia experiences growth. It can be seen from the increase in asset value from 2019 to 2020 .

The legal agreement which binds the parties is regulated in Civil Code Article 1338, containing the principle of freedom of contract [5]. In a legal act, the use of a media is known as an electronic transaction. According to Article 1 paragraph (2) of Law Number 19 of 2016 and Law Number 2 of 2008 about Information and Electronic Transactions, electronic transactions are legal acts which use electronic medium, such as computers, electronic networks, and others. Online insurance is a form of electronic transaction in which the parties use the internet network as a medium in carrying out all their transaction activities. Companies must obtain permission from the Financial Services Authority prior to carrying out insurance activities.

This is stipulated in Article 8 paragraph (1) of the Insurance Law that states "parties who wish to conduct insurance business activities must previously obtain permission from the Financial Services Authority." Insurance licensing regulation is stipulated in Financial Services Regulation Number 67/POJK.05/2016 about Business and Institutional Licensing of Insurance Companies, Sharia Insurance Companies, Reinsurance Companies, and Sharia Reinsurance Companies. In the future, the purchase of conventional insurance using manual methods through agents will see a decline due to a major growth revolution in the business that makes rapid growth in online insurance. 


\section{Results and Discussion}

\subsection{The Balance of Contracting In Online Insurance in the Revolutionary Era 4.0}

The definition of insurance by the Book of Trade Law and specifically stipulated in Law Number 2 of 1992 about Insurance Business states: "Insurance or Coverage is an alliance between the insurer and the insured, where the insured provides premiums and the insurer provides reimbursement in case of risk of an event or based on the life or death of the insured." In carrying out its business activity, online insurance does not have special regulations juridically, hence the regulation still refers to the Insurance Law. The difference between conventional insurance and online insurance is that in conventional insurance, the parties relate directly or face-to-face, while in online insurance the parties are not directly related, but rather use a medium of liaison.

Regulations related to online insurance policy documents have been allowed to be issued by regulators based on The Financial Services Authority in Regulation Number 23 of 2015 about Insurance Products and Marketing of Insurance Products. Online insurance arrangements are already being conducted in Saudi Arabia, regulated by the Monetary Authority of Saudi Arabia through the Insurance Aggregation Activity Arrangements [6]. Insurance is a form of agreement, therefore the valid terms of the agreement in the Civil Code and the specific terms in the Trade Law apply to insurance agreements. There are four valid terms of an agreement stipulated in Article 1320 of the Civil Code, namely the agreement of the parties, the prowess of the parties, certain objects, and lawful causalities. There are special terms stipulated in Article 246 and Article 251 of the Trade Law as well, namely: Payment of premiums and obligations to notify things known by the insured.

In general, the common format used in agreements is oral or written. As technology and the economy develops, a form of agreement with a more practical format changes into the standard agreement. The implementation of the standard agreement is intended for time efficiency. It is said to be "standard" because both the agreement and its clauses have been standardized and cannot be negotiated by the other party. In addition, with the development of the economy and technology, a new form of agreement can be done with online media. The purpose of the agreement is to achieve a balance of interests for the parties. Balance is very important; in fact, since the beginning, it has been the central point [8]. Achieving the balance of expecting on the objectivity of the future, efforts to prevent losses of one party. Understanding an agreement is a necessity and the balance of contracting is essential in the agreement. In the context of this study, "balance" is understood as a parallel state because no position dominates each other. In an agreement, balance is known as a principle which leads the parties to do and fulfill the contract.

In the agreement, the principle of balance demands rights fulfillment and obligations of the parties. The characteristics in the principle of balance are consistent, directed, and concrete. Mariam Darus Badrulzaman stated that the principle of balance is a continuation of the principle of equality, rights and obligations of creditors and balanced debtors where creditors have the right to demand the repayment of the debtor's wealth and the creditor is obliged to carry out the agreement in good faith [9]. In the business world, the use of standard contracts leads to problems. A balanced position is held by the parties to the traditional agreement. The negotiations conducted by the parties resulted in an agreement [10]. Under the standard agreement, there is no negotiation process between the parties. In determining the content of the agreement, it is almost impossible to negotiate. Generally, employers have determined the terms and contents of the agreement unilaterally. In the contracting process, the principle of balance is not reflected in the standard agreement. There is a positional 
imbalance in the clauses in an agreement. In the standard agreement contained an exoneration clause which is an imbalance of the agreement. This continues to happen because in standard agreements usage, there are economic considerations for budget efficiency, energy, and time when conducting the agreement process. However, it legally causes an imbalance of position because one party tends to accept the conditions that have been standardized and the other one accepts them under forced circumstances.

The force of law is influenced by the unfulfillment of the balanced element in the agreement. A balance can be created when there is an agreement between the binding parties without any pressure. In a balanced position, the parties have their rights and obligations that must be fulfilled. In a balanced position, the implementation of business activities can run better, thus helps the parties achieve their objectives. The role of balance in contract according to Herlien Boediono is that agreement, alliance, freedom in contract, and balance are full of expectations of a social role, in line with traditional social rules and rules of society[11]. This way, to determine whether an agreement is balanced or not, we must not only view from positive law but also from the balance towards the community. During the occurrence of an imbalance in the agreement, the principle of balance provides responsibility for the implementation of uniformity of norms as well as to determine whether there is a balanced agreement.

Transactions made via online media generally utilize the type of standard format that synchronizes the characteristics of the $\mathrm{B} 2 \mathrm{C}$ business model so that between the insurer and the insured there is no negotiation process. Thus, the agreement is created through the following terms:

a. Clickwrap agreement, which is a method of agreement on the implementation of transactions to buy goods or services through online media by consumers [12]. Consumers in making purchases through online media must agree to the terms stated in the existing standard contract by clicking on the icon (usually in the form of OK, I Accept, I Agree button).

b. Browsewrap agreement, an almost similar agreement to clickwrap agreement, only the difference is that consumers must read and agree to the terms already stated on the site before making a purchase transaction. These terms can be read in the Terms, Terms of Services, Terms and conditions, terms and conditions. When the consumer has agreed and continued the process, it is considered to have agreed in the online agreement.

If the consumer has agreed to the "clickwrap agreement" and "browsewrap agreement" system, the offer and acceptance have resulted in an online agreement. A deal is one of the valid terms of the agreement in accordance with Article 1320 of the Civil Code. In other words, the deal has resulted in a valid agreement. Prospective policyholders have an important principle called take it or leave it principle, where they are free to make all decisions to approve or reject. The characteristics of standard agreements in insurance result in policyholders having weak and unbalanced legal protections [13].

\subsection{Online Insurance Agreement Procedures}

Online insurance is one of the innovations formed as a result of technology development, where the company utilizes online media to conduct the entire process of targeting or selling its products. The use of online media as a distribution channel of insurance products is referred as Electronic Commerce (E-commerce), electronic media becomes a tool in trading goods and services [14]. In a narrow sense, E-commerce is intended for the scope of electronic trade in the form of trade via the internet (Internet Commerce), internet web 
facilities (Web Commerce), and electronic data exchange with a structured system (Electronic Data Interchange).

If the insured candidate has understood and is willing to comply with all the terms described in the initial information of the product, the insured candidate can make a purchase of the product by clicking on the "Buy Online" option. After the insured candidate clicks the "Buy Online" option, there will be a procedure that must be passed by the insured candidate in order to obtain insurance coverage. Generally, the Insurance Application Letter consists of a statement that the prospective insured agrees to bind themselves in the insurance agreement and is willing to comply with all the terms provided, such as allowing online insurance companies to use the information listed as a medium of policy communication and so on.

Table 2. Comparison of online insurance products at several banks in Indonesia

\begin{tabular}{|c|c|c|c|}
\hline $\begin{array}{c}\text { Online } \\
\text { Insurance } \\
\text { Products }\end{array}$ & Differences & Similarities & Advantages \\
\hline Bank X & $\begin{array}{l}\text { 1. Submitting claims } \\
\text { process with an online } \\
\text { system } \\
\text { 2. } \begin{array}{l}\text { Claim disbursement } \\
\text { within } 14 \text { working } \\
\text { days }\end{array}\end{array}$ & \multirow{3}{*}{$\begin{array}{l}\text { 1. } \begin{array}{l}\text { Purchasable via } \\
\text { online }\end{array} \\
\text { 2. Receive policy in } \\
\text { electronic form } \\
\text { 3. Have their own } \\
\text { websites and } \\
\text { applications } \\
\text { 4. Premium } \\
\text { payments made } \\
\text { through Auto } \\
\text { Debit Account, } \\
\text { Credit Card, } \\
\text { Virtual Account, } \\
\text { dan Bank } \\
\text { Transfer }\end{array}$} & \multirow{3}{*}{$\begin{array}{ll}\text { 1. } & \text { Can } \\
\text { purchased } & \\
\text { easily } & \\
\text { 2. } & \text { Easy } \\
\text { process } & \\
\text { 3. } & \text { Offer } \\
\text { access easy } \\
\text { applications / via } \\
\text { websites } \\
\text { 4. } \\
\text { Easier } \\
\text { premium } \\
\text { payments }\end{array}$} \\
\hline Bank Y & $\begin{array}{l}\text { 1. Submitting claims } \\
\text { process is not entirely } \\
\text { online } \\
\text { 2. Claim disbursement } \\
\text { within } 14 \text { working } \\
\text { days }\end{array}$ & & \\
\hline Bank Z & $\begin{array}{l}\text { 1. Submitting claims } \\
\text { process can be done } \\
\text { with both online and } \\
\text { offline system } \\
\text { 2. Claim disbursement } \\
\text { within } 30 \text { working } \\
\text { days }\end{array}$ & & \\
\hline
\end{tabular}

According to the authors of online insurance products, issuing electronic policies does not violate the applicable terms because before the electronic policy is issued, the online insurance company has requested approval from the insured candidate in advance through a statement contained in the Insurance Application Letter that states the insured candidate understands and agrees that the online insurance company will only issue the policy in digital or electronic form that will be received through the email address stated in the insurance application. Other shipping alternatives can be made by sending hardcopy at an additional charge. E-policy will be sent immediately after making payment. 


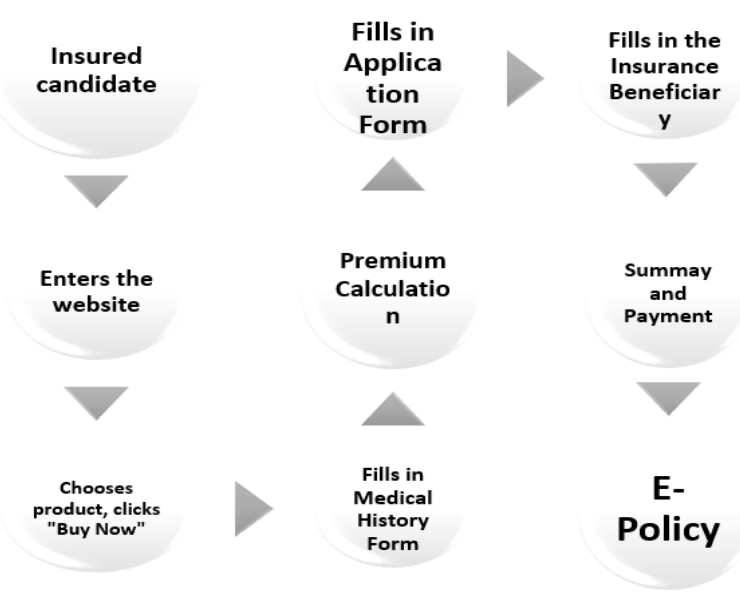

Fig. 1. A summary of online insurance agreement procedures in general

\subsection{Legal Consequences Incurred In The Event of Default on Online Insurance Agreements}

In an agreement, the possibility of a default exists. Default is a disappequality or unfulfillment of achievement in an agreement [15]. Actions that are considered as a default are achievements which actions must be intentional / neglected, unfulfillment of achievements, imperfect achievements implementation, late fulfillment of achievements, and violations that are prohibited in an achievement. In online insurance agreement implementation, the form of default that can be done by the parties is the unfulfillment of the agreed obligation, namely unpaid premiums by the insured and unpaid compensation by the insurer. Policyholders are obliged to provide correct personal data information to the insurer, understand the contents of the agreement, pay premiums, and carry out other obligations in accordance with the policy contents.

If there is an incorrect information, the insurer reserves the right not to approve the insured's insurance application. Late payment of premiums can result in the policy becoming void (lapse) and not getting the benefits of insurance claims. According to Article 251 of the Trade Law governing good faith, the cancellation of an agreement is due if all information provided is incorrect, hiding the truth of the insured in accordance with the conditions if known to the insurer [16]. The Insured gives confidence to the insurer to carry out the principle of good faith. The insurer in good faith must explain the guarantees and rights of the insured [17].

The establishment of insurance business in accordance with the procedure requirements stipulated in the Financial Services Authority with an online system can be done by all types of insurance businesses. According to Article 1 paragraph 2 of Law Number 11 of 2008 about Electronic Information and Transactions, it is stated that electronic transaction is a legal act with the use of electronic media, such as computers, electronic networks, and others. The parties conduct trade transactions in the form of electronic contracts. Electronic contracts are regulated in Article 1 paragraph 17 of Law No. 11 of 2008 concerning Electronic Information and Transactions is an agreement made in the electronic system for all parties. If the online insurance agreement is defaulted, the things that can be taken are all disputes between the insurer and the insured can be done by deliberation and consensus. 
However, if the dispute cannot be resolved by deliberation and consensus, the insurer and the insured can choose a settlement through the court or through the Indonesian Insurance Mediation and Arbitration Agency or through other alternative dispute resolution institutions established by the Financial Services Authority.

\section{Conclusion}

According to the author on online insurance products, there is a balance with the fulfilment of the rights and obligations of each party and also through the Letter of Application for Insurance that has been agreed by the parties. During the application for insurance, customers are also free to choose the type of product, benefits received, the amount of premiums, the period of coverage in accordance with the will and needs of the customer. After that, the insurance company must fulfil its obligations in accordance with the applicable policy. Both parties also benefit from each other, namely customers get a feeling of protection from all possible risks and insurance companies get a profit called premiums.

Simply put, insurance products which process ranges from information search, product selection, planning, assessment of risk / underwriting, negotiation, contract signatures, payments, to claims made by using electronic or digital devices for certain products, there are some processes that must be done conventionally, but overall online insurance is more focused on electronic mechanisms (software or applications). If the online insurance agreement is defaulted, the things that can be taken are disputes between the insurer and the insured can be done by deliberation and consensus.

However, if the dispute cannot be resolved by deliberation and consensus, the insurer and the insured can choose a settlement through the court or through the Indonesian Insurance Mediation and Arbitration Agency or through other alternative dispute resolution institutions established by the Financial Services Authority.

\section{Suggestion}

The Government and the Financial Services Authority should establish a clearer regulation in online insurance implementation rules as a legal protector for the insurer and the insured. Online insurance companies as insurers ought to provide more detailed information, so the insured can understand the insurance products better and the prospective insured is expected to provide the correct information without committing fraud, understand, and implement the agreement in all conscience.

\section{References}

[1] Zainul Hakim, Ika Nuraeni K dan Heri Yulianto: Pembuatan Pengajuan Jaminan Surety Bond Berbasis Online di PT Generasi Prima Solusi. AJCSR [Academic Journal of Computer Science Research]. Vol. 2 No. 1, January 2020.

[2] Febrian Indar Surya Kusuma dan Sapto Hermawan: Examining on Indonesian Legal Challenges for Future TransnationalHealthcare Service. Brawijaya Law Journal Vol.7 No.1.

[3] D Kamarudin D Mudin (dkk): Industrial revolution 4.0: Universiti Malaysia Sabah perspective, E3S Web of Conferences, Volume 48, 08 August 2018.

[4] https://www.ojk.go.id/id/kanal/iknb/data-dan-statistik/asuransi/Default.aspx, accessed on 07 Februari, 2021. 
[5] Muskibah dan Lili Naili Hidayah: Penerapan Prinsip Kebebasan Berkontrak Dalam Kontrak Standar Pengadaan Barang Dan Jasa Pemerintah Di Indonesia. Fakultas Hukum Universitas Kristen Satya Wacana. Vol. 4 No. 2, April 2020.

[6] Regulation of online insurance intermediary activity in Saudi Arabia (atlas-mag.net), accessed on 04 Januari, 2021.

[7] Shohib Muslim, Khotbatul Laila: Hukum Bisnis, Polinema Press, Malang, 2018.

[8] Siti Malikhatun Badriyah: Sistem Penemuan Hukum dalam Masyarakat Prosmatik. Jakarta: Sinar Grafika. (2016)

[9] Mariam Darus Badruizaman: Aneka Hukum Bisnis. Bandung: lumni. (1994)

[10] R.M Panggabean: Keabsahan Perjanjian dengan Klausul Baku. Jurnal Hukum Ius QuiaIustum. 17(4). (2010)

[11] Nurdianita Fonna: Pengembangan Revolusi Industri 4.0 dalam Berbagai Bidang, Guepedia (2019)

[12] Yahya Ahmad Zein: Kontrak Elekronik \& Penyelesaian Sengketa Bisnis E-Commerce Dalam Transaksi Nasional Dan Internasional, Mandar Maju, Bandung. (2009)

[13] Fajrin Husain. Perlindungan Hukum Terhadap Pemegang Polis Asuransi Menurut UU NO. 40 Tahun 2014 Tentang Perasuransian, Lex Crimen Vol. V No.6 Agustus 2016. (2016)

[14] Edmon Makarim: Kompilasi Hukum Telematika, Jakarta, Raja Grafindo Persada (2004)

[15] Hillary Ayu Sekar Gusti, Wanprestasi Penjual Dalam Perjanjian Jual Beli E Commerce, Universitas Islam Indonesia, Yogyakarta. (2018)

[16] Eti Purwiyanti ningsih. Prinsip Itikad Baik Berdasarkan Pasal 251 KUHD Dalam Asuransi Kerugian, Fakultas Hukum Universitas Jenderal Soedirman Purwokerto, Jurnal Dinamika Hukum, Vol. 8 No. 3 September 2008. (2008)

[17] Undang-Undang Nomor 2 Tahun 1992 Tentang Usaha Perasuransian (Lembaran Negara Republik Indonesia Tahun 1992 Nomor 13, Tambahan Lembaran Negara Republik Indonesia Nomor 3467);

[18] Undang-Undang Nomor 11 Tahun 2008 Tentang Informasi Dan Transaksi Elektronik, (Lembaran Negara Republik Indonesia Tahun 2008 Nomor 58, Tambahan Lembaran Negara Republik Indonesia Nomor 4843);

[19] Undang-Undang Nomor 40 Tahun 2014 Tentang Perasuransian (Lembaran Negara Republik Indonesia Tahun 2014 Nomor 337, Tambahan Lembaran Negara Republik Indonesia Nomor 5618). 